\title{
The African concept of caring for life
}

\author{
Maake Masango \\ Department of Practical Theology \\ University of Pretoria
}

\begin{abstract}
This article analyses the village concept of caring among African people. The old pattern of caring was based on the concept of ubuntu (humanity) which respects people, because they are created in the imago Dei. Then the article compares the western concept of caring, which is based on individualism and people's privacy. Finally, economy, globalisation and this western concept are analysed. The impact of the above concepts affects Africans in urban areas, who are caught up in the two worlds, namely the African and western worlds.
\end{abstract}

\section{CARING}

The concept of caring is a gift from God for all human beings, as well as animals. I cannot imagine what life would be like without caring for one another. In other words, your life and mine would be unimaginable without the care, guidance and support of parents, uncles, aunts and other human beings. In fact, caring occurs from the time of conception, right up to the time of death. Waruta reminds us of several ways in which caring and support occur:

- The physical, emotional and spiritual nurturing (care) by our parents and guardians when we were tiny helpless babies - this caring was a natural response;

- The early childhood friends and peers with whom we grew up and learned the joys and frustrations of becoming up;

- The turbulent adolescent stage in our lives when our capacity to relate to other people became not only our main concern, but also the source of anxiety as we sought to understand ourselves and establish our own identities; 
- The struggle to find our own places and survive in the competitive, sometimes hostile world of young adults;

- The excitement and crisis of establishing and maintaining a family in our adult years;

- The crises of finding meaning and purpose for our lives in middle age;

- The support of family and society as the time approaches when we will bid farewell to this life and our physical strength continues to diminish (Waruta 2000:1).

Along this journey of life we need other people to care for us, just as they need someone to care for them. The above description of care reminds us how much we depend upon one another for survival. From little ones who are seldom given recognition to those whom the world deems significant (e.g. Tutu, Mandela, De Klerk and Ghandi).

\section{AFRICAN CONCEPT OF CARING}

One could ask what the African concept of caring is? And how does it differ from the western concept of caring?

The African concept of caring involves all the members of the village or community, family, relatives, tribe and ancestors. In the African community, life is lived with others in a group, tribe or clan. There is no individualism or privacy accepted in the village. Getui reminds us vividly about our responsibility in the village. She states: "It is the responsibility of the whole village to care for life, especially of the young and old. It is also our responsibility to help them towards the restoration of the wholeness" (Getui \& Theuri 2002:176).

In the African community or village, human life is sacred and must be preserved, defended, supported and enhanced as a matter of priority above everything else. I agree with Kobia's statement that: "The most crucial and critical aspect of this engagement is grounded in a vision of life as a web of reciprocal relationships by which human beings find themselves interconnected with one another, and with the rest of creation" (Kobia 2003:1).

It is important to note that the sanctity of human life is based on the doctrine of the imago Dei. Waruta makes this comment about the imago Dei: "Human beings are created in God's image, and that, whenever human life is undermined or destroyed, God seeks ways of restoring it within the village" (Waruta 2002:16). In other words, those who engage in the task of restoring 
(caring for) the wholeness of human life are co-workers with God in the primary task of perfecting divine creation. By contrast, Kobia emphasises that "the fullness of life, shared by all created things is experienced in the harmony of the interdependence, and in their common dependence on God, the ground of all being" (Kobia 2003:9). Sharing life together in the village reminds us of God who created us. As we care for one another we also care for God who created us. The African proverb sums up the concept of caring in a beautiful way: "It takes a whole village to raise up a child" (Zondi 1996:62).

In spite of the above quotation, African people still have weaknesses in their caring systems, because of confusion of trying to live their lives while being influenced by a western lifestyle. As human beings, we still need the support of others; yet such support is at times inadequate owing to the changing situation in the world. The problem we encounter is that we are not all equipped to care adequately, because we do not all have the gift of caring. For example, our own personality could be the problem even though we might often blame others for our shortcomings. Waruta reminds us that "caring is the art and skill of helping individuals and groups in order to understand themselves better, and are able to relate to fellow human beings in a mature and healthy manner" (Waruta 2002:2).

For people to care in an appropriate way, we need to learn from those who nurture them. Psychotherapy teaches us that if our mentors are abusive, we will end up being abusive too. My growing conviction is that people turn to caring or nurturing correctly, because they want the opportunity to examine themselves and their problems in the light of their faith and their religious tradition, with the help of an expert or mentor. The root of caring is related to God who created all of us in his own image. The concept of ubuntu becomes important as it is also linked to the imago Dei. This concept continues even when a person dies. Therefore the concept of ancestors in African life is connected to the caring ministry. The belief among Africans is that their ancestors are closer to God than they are. Most of the ancestors are saints, especially those who lived a good and exemplary life. But some ancestors are not saints - those who lived a bad life are not regarded as good, because they failed to care for others. They cannot be incorporated in the continuation of caring for others. They are forgotten, because their influence may affect the structures of caring in the village. Those who are alive and participate in caring for the sick are also caring for God. For example, anyone who cares for people infected with HIV/Aids is therefore taking care of the sacredness of human life, which is imago Dei. As villagers continue to care for a sick person, the caregivers are aware of the spiritual element of that person's life. Caring in the village continues from the cradle to the grave. 


\section{The African concept of caring for life}

One could ask a question, how does the Western world view life? I came across an interesting maxim by John Donne, which summarises the western concept of life: "No man [woman] is an island, entire of itself". This idiom challenges the western concept of respect for individualism. This concept not only affirms the African way of living, but also reminds us of other people. The western concept expresses respect for the individual and allows a person to have some personal space; though the African concept of life may sometimes crowd and overshadow one's personal space. In the western world, one can become lonely even though there are people around you who could care for you or your life. The western world rotates around selfcenteredness, privacy and respect for personal space. Yet as an African, I realise that this concept destroys the quality of human life through loneliness and isolation. Descartes describes a person in the western world in terms of cogito ergo sum, which means "I think, therefore I am" (Mbiti 1997:80). In this kind of world, individualism creeps in and introduces a spirit of competition and self-centredness. In the African village, the principle of ubuntu introduces a concept of belonging. When Africans meet and greet one another, they say in Zulu: "Siya kubona umfowethu" (I see you my brother or sister). The person so greeted will respond by saying "Ngiya ku bona umfowethu" (I see myself in you, my brother or sister).

This concept of greeting has elements of affirming and caring for the life in one another. It also introduces another important concept of living, called ubuntu. Mbiti is helpful because he leads us deeper into respect for the human dignity that God has given as a gift to humanity. He states that ubuntu means: "I am because you are, you are because I am" (Mbiti 1969:61).

This living concept of respect and relating to one another flows through our daily lives. When taken seriously, it can correct the way the western world and globalisation have destroyed human dignity, which is leading Africans to adopt the western concept of individualism. People in the rural areas still follow the traditional patterns and respect life as a gift. That is why villagers ask anyone who is experiencing difficulties in life whether he/she has any broken relationship with someone or if he/she has offended someone, because people in African village associate sickness with broken relationships. Kobia speaks about the power of relationships as a force that lives in communities and keeps people alive. He states: "This force resides in all human beings and keeps us alive. It is brought to fruition in birth, sustained and nurtured in the rich network of communal relationships and transferred back to the community in the spiritual realm through death" (Kobia 2003:17).

In other words, the power of a relationship is a force given to us in so that we can relate to and work with one another. It is another way of caring, 
which is introduced as a new concept of caring for life. It is also a responsibility bequeathed upon all human beings by Modimo (God), and overseen by the great ancestors. A relationship continues even after death. So, when things go wrong in life, you are asked to examine your relationship with those who are alive, especially those you might have offended. You are then challenged to heal those relationships so that you will be able to relate to others. You are forced by circumstances to repent and then reconcile yourself with others. This is similar to the concept of confession practised in some churches of the modern western world. As African people connect sickness with broken relationships, Kinoti comments that "human crises have a spiritual dimension, and they cannot be fully overcome until the spiritual yearning of the human being have been met in relationship" (Waruta \& Kinoti 2000:7). In short, a broken relationship in African life is connected to the Old Testament as well as the New Testament, for example when people came to Jesus they asked a question about the blind man: who sinned? His parents or the blind man?

Broken relationships lead to alienation, which has to be healed in the process of restoring wholeness. The main source of alienation in the village includes disconnection with the spiritual elements of life. Therefore the Africans believe that disjointed or disrupted value systems often precipitate misery. Caring in an African village is never content with satisfying the physical and mental disposition of a person, but continues until that person is restored to spiritual health. All the above concepts involve the whole community of the villagers, family, tribe or clan - even animals are included. The aim of caring in the village is to guide people to establish new and healthy relationships with other people. The emphasis is on the mind and the soul (spirituality).

\section{HEALING AS PART OF CARING}

The African Independent Churches introduced another helpful element to worship. They believe that faith in God (especially for healing) is the basic source of victory and a fulfilled life. Physical and spiritual healing are important parts of wholesome healing. The two elements complete the process of reconciliation. The concept of caring that leads towards healing is inconsistent with the instructions in the Bible that we ought to be "keepers" of our brothers or sisters. For example, the family will spend all they have in order to seek healing for the one who is sick. At times they will take the sick person to a place called Diagelong (a place used by the independent churches where they care and heal the sick). The family will collect money; neighbours will also help to pay for treatment. Although it is not possible to solve all problems or 


\section{The African concept of caring for life}

heal all diseases, caring for African people endeavours to help those who are in difficulties, without presumption and triumphalism. When a person dies in Diagelong, you will often hear the prophet or healer saying to the family in SeSotho "Repaletswe ke go disa" (meaning, we are defeated and could no longer care for the person). If a person becomes handicapped for life, African people have another way of caring, i.e. when all avenues have been explored, and there is still no healing process, or a person is now handicapped, their caring changes and follows the direction of encouraging the afflicted persons to live with their problems until such time as solutions could be found, or if God intervenes. If they are chronically ill, people will continue encouraging the sick, through their physical presence by visiting them, by prayer, bringing food, reading a Bible verse, or just extending a loving touch or embracing them. Family members, neighbours, church members and co-workers will visit those who are in hospital. They will sing and pray not only for them, but also for all who are in the ward in the hospital. Caring is a community effort. The Western world may find this concept disturbing to their peace, quiet and individual space. I was once confronted by a white patient who said to me as a leader that we were making a noise (while singing). The above incident reminded me that a single person's individualism and the question of personal space are important in western culture. Our singing and our prayers in that ward in the hospital were therapeutic to African people, but a problem for the white patients. Mugambi shares this concept and explains it as follows:

"Sometimes the most therapeutic activity in pastoral care is the assurance that exudes from human love, with such words as: I am here, I am with you, and I care" (Mugambi 2000:52).

It is important to note that in times of deep crisis and suffering, the individual's greatest need is for the presence of God's people who care about and understand that individual. Wimberley comments as follows about the presence of God: "It is true, of course, that African people acknowledge the reality and presence of God; but their desire for wholeness and fulfillment that comes from an intimate relationship with God and fellow neighbors is important" (Wimberley 2002:90). The church should encourage this kind of relationship through worship and prayer. We should take care not to use religion as a scapegoat.

Prayer is another element of support. Given the situation of fundamentalism and charismatic elements, one needs to be careful to avoid hiding in religious escapism, merely engaging in endless prayers or casting all burdens on the Lord, and leaving them there. The presence of God is important. There are churches whose members pray for people infected with HIV/Aids, and later tell them that they are healed. There are also families who 
pray for healing miracles in their churches. This sort of ministry places a burden on families and those who are sick. Though I do not doubt the power of the Holy Spirit, we need to be aware of "wolves in sheep's clothing especially in these days of high unemployment. Various people or healers engage in practices that destroy life. These changes in their way of life are turning Africans in urban areas away from the African concept of healing and caring for life. Others try to uphold two traditions, i.e. the western as well as the African. In an endeavour to correct the above, Waruta advises that "care givers (or pastoral counsellors) should engage a complementary interchange between faith and science, which are both gifts from God" (Waruta 2000:7).

The challenge is how we continue to care for the terminally ill. It is a fact that Aids has no cure, therefore we should not give Aids-infected people false hope about healing. Some churches in African communities ask people to come for healing yet these churches know the people will not be healed. Our ministry of caring should therefore be to help educate people so that they will use medications which will sustain their lives. As we care for sick people through prayer, we should also match this with caring through medicine. This way of caring, that is holistic caring, will help restore our fellow human beings to physical, emotional as well as spiritual health. As followers of Christ we know that the healing ministry of our Lord was concerned with wholesome healing. For example, Jesus looked at the people of Jerusalem, and his heart was filled with pity for them, because they were worried and helpless, like sheep without a shepherd (Mt 9:36).

The above picture of the old days of Palestine is familiar to us in contemporary society. This is a challenge for African churches. To be worthy of their name, the African churches should be willing and prepared to confront human suffering, and the conditions that cause it, by following the example of their founder, Jesus Christ. The African churches need to take up their prophetic ministry by confronting those who abuse people by promising them healing, though they know that these people are terminally ill. In this way the church will care for the healers as well as the sick. The first question is how we can be the "keepers" of our brothers and sisters? The second question is the issue of finance. Lastly, we should analyse the issue of justice in a world full of injustices. This would also include financial assistance, while caring for those who are sick. Families may spent fortunes seeking healing for someone who is infected with the HI virus and so-called "healers" will keep on taking their money while knowing that these sufferers cannot be healed. 


\section{GLOBALISATION AND FINANCE}

Nowadays people's financial means will dictate how they will receive care, especially in hospital. The concept of the financial ability to pay for medical care is a serious challenge to developing countries and also affects African communities and their care. Schweiker, speaking about blessings, claims:

Divine blessing is often tied to prosperity and progeny, and even in the parables of Jesus, the awareness that a worker is due his (her) wages. Of course, within these parables, the extravagance of the divine reign is present in such a way as to overturn normal patterns of economic distributions.

(Schweiker 2000:28)

Economic variables determine what medical care people will receive. The biblical parable tells us that those who have the least are given the most, and the faithful son is not welcomed with the same abundance as the prodigal son. Care has become commercialised, and is challenging the patterns of caring in African communities. Financial means or the lack of them has become a threat to moral and religious people, as well as to village life. The church ought to challenge evil structures wherever they exist, especially evil structures that divide people to the extent that they become self-centred. Our Lord addressed such structures, but also bade his followers to trust in God, not wealth, for the necessities of life. For example, he said that one cannot serve God and wealth: "No one can be a slave of two masters, he [she] will hate one and love the other, he [she] will be loyal to one and despise the other. You cannot serve both God and Mammon" (Mt 6:24).

The above issue has been a bone of contention in the church. For example, the early church fathers such as Tertullian and Chrysostom fought against the danger of wealth and possessions. To them "Mammon was taken to be the name of the demon of riches or a Canaanite god" (Schweiker 1998:86). St Augustine also notes that "some things are to be used and others loved. Money is to be used, but only God is the fit object of ultimate love and enjoyment" (Schweiker 1998:91).

The main advice given by the early church fathers is that we should avoid confusion, especially where people come to enjoy what ought only to be used - when they mistake what is not God for God (in other words, they become sinful). If we note how money is used nowadays, we realise how it changes the values and ethics of caring among the members of communities. For example, modern hospitals first ask whether a patient has medical insurance or belongs to a medical aid scheme before they will admit the patient. In other words, one has to pay first before care will be given. In the 
olden days it was a common practice to ask your neighbour to care for your sick mother, while you went to town or to work. But those times are gone: if you make a similar request today in urban areas, the person expects some form of payment. In the past, it was part of our responsibility to care for one another. Money has now become a demon and is destroying the concept of ubuntu (humanity) among the members of our communities. The concept of the imago Dei is destroyed daily by regarding money as valuable and important. In the western world and culture, I would sound foolish if I did not ask for money or payment for a service I rendered to another person. Caring is connected with payment. For example, in the western world you pay a person to care for your mother in an old-age home. The African heritage uses an idiom to expresses caring for one another: Matsogo a ya hlatswana, which means one hand helps to wash the other hand. In other words, by helping another person you are helping yourself. Money is destroying our communal lifestyle of caring for one another. It also has an adverse effect on the relationships among African people. It should be noted that money is there to be used, but only God is the fit object of ultimate love and enjoyment. What is interesting too is that during the Middle Ages and the Renaissance, money was personified as greed. Sir Epicure Mammon, when referring to the greedy knight of Ben Johnson's The Alchemist, states: "Mammon evokes fascination, grows into devotion, and finally enslaves people" (Moltmann 1999:79).

The struggle for money has been part of our lives and will continue to tempt us to neglect our duties of caring for one another. In the western world money is seen as a basic social power, but in the African world it destroys the African concept of caring for life. One can begin to see this destruction of caring among Africans in South Africa's new democracy. Money in the western world is also seen as a sphere of life necessary for human existence, but tends to encompass the whole of life, and in doing so reveals demonic features. Human beings tend to cause problems by creating systems of meaning that are self-negating. Before the HIV/Aids pandemic, I had never heard of an African family leaving their dead to be buried by the government. Yet this is happening nowadays to the victims of HIV/Aids. When one challenges the family they respond that they have no money. In olden days, the villagers would meet to help the family by collecting money for burying the dead. This abandonment of their dead is challenging the old values of caring from the cradle to the grave. Urbanisation and globalisation have introduced African people to new concepts that are destroying ubuntu, even though some of these new concepts have brought benefits to our lives. The prophetic ministry of the church is called upon to challenge to these evil structures, this monstrous Mammon that now dominates our lives. In short, economic activity 


\section{The African concept of caring for life}

and financial values must be set within, limited by, and judged in accordance with more basic morals and religious norms. Our Christian ethics should focus on how industrialised market-driven societies could become consistent with the issue of justice, for the common good of all human beings. In this way the church will become the voice of the voiceless when challenging the demonic powers that seek to destroy humanity. We are therefore challenged as Africans to address the issue of justice, especially when dealing with the issue of caring. The reader should be aware that justice in the African community respects life. In my opinion, human dignity ought never to be subordinated to economic practices which destroy people. This is where a commercial culture fails most profoundly. We need a set of values, and a picture of human dignity to contrast with the demons that now dominate the value of life. Van Deusen Hunsinger reminds us: "... so also human beings are not meant to be isolated but rather in relationship. God created human beings to relate to other people in faithful, mutually giving and helping love, and in a concern for the poor and caring for the weak" (Van Deusen Hunsinger 1995:20). This statement ought to be taken seriously, because it would help us restore human dignity in globalisation.

\section{CONCLUSION}

African people need to return to the basic values of village life so that they can recover the concept of caring. The emphasis in the African village community is on communal life, which leads to respecting human dignity and ultimately the preservation of life. Once this concept has been revitalised, codes of living and caring for one another will be respected. We cannot afford to live private and individualistic lives focusing on our own interests. We need each other in order to survive, especially in the globally oppressive world. We are meant to live with one another; in fact this is the gift we Africans have and could introduce to the western world. Finally, as a united community we will be able to face the common enemy that seeks to destroy our dignity, and our African concept of caring for one another. Masamba Ma Mpole explains a concept which aptly concludes this article: "Group members in the village who have a clear sense of purpose and commitment, are able to defeat demonic powers that seek to destroy families, as well as tribes" (Masamba Ma Mpole 1984:45). We have to continue fighting against individualism which has led others to become self-centred instead of mutually caring. 


\section{Works consulted}

Burger, A P 1996. Ubuntu, cradles of peace and development. Cape Town: Kagiso.

Donne, J Meditation XVII, in Concise Oxford Dictionary of Quotations, 1982. Oxford: Book Club Associates. (by arrangement with Oxford University Press.)

Getui, M N \& Theuri, M M (ed) 1996. Quests for abundant life in Africa. Nairobi: Acton Press.

Kobia, S 2003. The courage to hope: The roots for a new vision and the calling of the church in Africa. Geneva: World Council of Churches.

Masamba Ma Mpolo 1984. Family profiles stories of families in transition. Geneva: WCC Publications.

Mbiti, J S 1977. Introduction to African religion. London: Heinemann.

Moltmann, J 1999. God for the secular society: The public relevance of theology. Minneapolis, MN: Fortress Press.

Schweiker, W 1998. Power, value and conviction: Theological ethics in the postmodern age. Cleveland: The Pilgrim Press.

Stockhouse, M L, Dearborn, T \& Paeth, S (eds) 2000. The local church in a global era: Reflections for a new century. Grand Rapids, MI: Eerdmans.

Van Deusen Hunsiger, D 1995. Theology and pastoral counselling: A new interdisciplinary approach. Grand Rapids, MI: Eerdmans.

Waruta, D W \& Kinoti, H W 2000. Pastoral care in African Christianity: Challenging essays in pastoral theology. Nairobi: Acton Publishers.

Wimberly, A E \& Parker, E L 2002. In search of wisdom: Faith formation in the black church. Nashville, TN: Abingdon Press. 